\title{
The Influence of CEO Personal Characteristics on the Market Value of Russian Companies
}

\section{Liudmila Ruzhanskaya}

Doctor of Science in Economics, Associate Professor, Head of Academic department for International Economics and Management

$\underline{\text { ORCID }}$

E-mail: 1.s.ruzhanskaya@urfu.ru).

Graduate School of Economics and Management, Ural Federal University, Ekaterinburg, Russia

\author{
Anatoly Sizikov \\ Researcher \\ $\underline{\text { ORCID }}$ \\ E-mail: anatolysizikov@gmail.com \\ Graduate School of Economics and Management, Ural Federal University, Ekaterinburg, Russia
}

Journal of Corporate Finance Research, Vol. 14, No. 4, pp. $19-30$ (2020)

DOI: https://doi.org/10.17323/j.jcfr.2073-0438.14.4.2020.19-30

Received 15 October 2020 | Peer-reviewed 23 October 2020 | Accepted 24 October 2020 


\section{The Influence of CEO Personal Characteristics on the Market Value of Russian Companies}

\section{Abstract}

This paper analyses the impact of a CEO's demographic and professional characteristics on the market value of the company. The growth of company capitalisation involves the expectations of investors specifically their view of the personality of the CEO, including whether he will be able to maintain the proper level of the company's work and whether there is expediency in further investment. Therefore, it is extremely important to understand exactly what qualities of a top manager influence investor expectations.

This research is based on data from the 50 largest public Russian companies from non-financial sectors for the period 2011-2019, and iformation is included on 98 CEOs across this period. Herein we define the mechanism of the relationship between the personal characteristics of the CEO and the market value of the company.

Based on a pooled regression assessment, our results indicate that the level of education of the CEO is an insignificant variable, and practical experience is valued higher than academic qualification (this is consistent with the results of previous studies). The market responds positively to the appointment of executives with industry experience. The experience of a CEO in a prior governmental or state role impacts negatively on firm value, and the status of the company's founder is met with optimism by the market, seeming to assure an interest in strategic development. The status of an outside manager is rated higher by the market than a successful career inside the company. The optimal age of the head of the company from the point of view of positively influencing the value of the company was determined at 49 years.

We conclude that a portrait of the head of a large traded Russian corporation has been constructed in the present work, which contributes to the literature on optimal market perception for businesses and manager.

Key words: CEO, market value of the company, demographic characteristics of the CEO, professional characteristics of the CEO

JEL classification: G32, G34 


\section{Introduction}

The personal characteristics of top managers play a role in any team, but for publicly traded companies, they also act as signals to financial markets about a firm's stability and possible strategic directions of development. What distinguishes top managers from the $\mathrm{CEO}$ is that the $\mathrm{CEO}$ is responsible for the company's activities in general and reports only to the owners of the company and their representatives. Unlike other managers he has more decision-making power which is accompanied by a higher degree of responsibility. The CEO represents the interests of the owner in relation to employees and joint organisations [1].

Research in the field of corporate governance uses the 'upper echelons' theory to substantiate the influence of demographic and professional characteristics of managers on the company's performance [2]. A counter-argument to this point of view is represented by the observation that managers, being limited by the actions of corporate monitoring mechanisms and the external business environment, are restricted in their actions. However, these circumstances do not significantly affect the company's activity [3-5]. As an alternative direction for studying the relationship between the personal characteristics of a manager and the performance of a firm, we will seek to identify the conditions wherein this relationship appears most significant. Where a final understanding hasn't been reached [6], this may be a result of differences in the institutional environment of different countries, in the economic situation, and in socio-cultural traditions. This article aims to make up for the lack of research on Russian data on this topic with the use of a wide range of demographic and professional characteristics of top managers. An additional task is to establish whether after 30 years of reforms the reaction of financial markets and the corporate governance model is still strongly influenced by the legacy of the "Soviet past", which leads to a significant difference between the results of domestic studies and the results of works on samples of other countries.

Thus, the purpose of this research is to evaluate the impact of the demographic and professional characteristics of the CEO of the largest traded Russian companies on their market value.

\section{Literature review and research hypotheses}

The dependence of financial indicators on the managerial abilities of the head of the company was substantiated in the 'upper echelons' theory [7]. As proxy variables to determine the managerial abilities of top managers, it is proposed to use the following series of observed characteristics: age, education, work experience, and career history. However, using only demographic variables leaves open the question about the impact of the real psychological and social processes that govern the behaviour of top management. Scientists call this challenge the 'black box problem' [8-9].
To explain the personal characteristics of the mechanism of the positive impact of the CEO on the effectiveness of a company, we used the analytical category of 'commitment to the organisation'. Emotional commitment is defined as "an emotional attachment to an organisation with which the person involved in membership in the organisation is clearly identified" [10]. Existing research shows that leaders with high levels of organisational commitment would like to see their company was doing well and shows good results [11-12].

The list and nature of the influence of each of the demographic and professional characteristics analysed in our model on the company's market value is given below.

\section{Demographic characteristics.}

1.1. Gender CEO. A positive relationship between female participation in the top management of a company and its gross profit was found [13]. However, the authors of the work cited at reference [14], conducting a similar study, used the Tobin's Q coefficient to represent the company's financial performance, and did not find a positive relationship. A meta-analysis of 140 papers led to the conclusion that female participation in the top management of a company has a positive effect on its balance sheet indicators; this relationship is most pronounced in countries with a higher level of shareholder protection [15].

1.2. Age CEO. Researchers in the paper cited at [7] suggested that young leaders are more inclined to take risks and take more strategically important actions. However, another work [16] found a positive effect of age on balance sheet indicators. The authors explained this by the fact that a top manager at a certain age pays more attention to profit maximisation, which affects the size of the bonus payments. The authors of another work [17] came to a similar conclusion. In research number [18] the authors concluded that firm success is positively correlated with increasing CEO age. This is explained by the fact that the younger the CEO, the more inclined to take risks, which does not always have a positive effect on the firm's performance.

1.3. Citizenship CEO. For companies in emerging markets, attracting top managers (expats) from foreign developed economies is associated with the transfer of effective management technologies and best practices. In addition, foreign executives can exercise independent control over Russian managers and have extensive business contacts abroad. The world labour market for top managers is much wider than the national one. This statement applies particularly in the case of Russia [1]. Nevertheless, attracting foreign leaders can be associated with a certain number of challenges, including difficulty in adapting to the socio-cultural characteristics of the country, and a lack of understanding of the specifics of the Russian market [19]. Also, the costs associated with finding, hiring and moving a foreign manager can be significant [20]. Studies analysing the effects of citizenship of top managers on the effectiveness of the company utilise not merely the fact of citizenship but the experience of management abroad 
[3; 21]. A positive relationship was found between a CEO with foreign experience and firm performance, but a stronger relationship was observed for international companies. In the case of Russia, expats tend to have international experience, so foreign citizenship can be strongly correlated with international experience.

\section{Professional characteristics.}

2.1. Tenure in current position. In earlier works, scientists tried to find a linear relationship between these variables and determine the effect of the length of time the CEO has held their current position on the financial performance of companies [20]. A negative effect of longer duration for the company's management team was found with regard to company growth [22]. The negative effect is perhaps explained by the fact that managers who work for a long time within the same company adhere to regular and unchanging strategies, and they become adherents of their own static ideas. As such, they are less prepared to e.g. introduce fundamentally new technologies which negatively affects the expectations of investors but benefit the value of the company's shares. At the same time, some research [23] was able to identify a positive effect of the duration of the current position on the profit margin. The positive effect is that a long-serving CEO has already formed a successful company management strategy, and is aware of all internal processes and is well-versed in the industry. However, other studies failed to find a significant effect $[19 ; 24]$.

2.2. Work experience as a CEO: in the same industry, in a similar position, in this company. One of the ways to accumulate human capital is to have work experience in a similar industry, which assumes that the manager knows the peculiarities of its functioning, successful and unsuccessful examples of business models of other companies in the industry, the specifics of interaction with the government, and potential counterparties [1]. Work experience gained in a similar environment can be quite valuable for a CEO, as it helps to accelerate the adoption of strategically important decisions [25]. From this point of view, there is reason to believe that experience in a similar industry can positively influence a company's performance. According to estimates obtained in earlier studies (see e.g. [26]) the share of cross-sectoral movements of the heads of Russian companies is only $8 \%$ of the total number of transfers. This means that CEOs are focused on developing industry experience, because this is a more successful hiring strategy.

2.3. Experience in public service. There is no consensus among researchers as to how political ties affect a company's performance. In some studies, it is concluded that the political connections of the CEO have a positive impact on the company's activities [27-28]. It is assumed that a leader with political connections has access to limited resources which provide a competitive advantage. Such resources include new sources of funding, tax cuts, etc. The authors conclude that executives with experience in the public service are less likely to be removed from their positions because owners value their contributions through political connections [28].

On the other hand, the political connections of a CEO reduce the incentives of the top manager to look for more effective ways to solve strategic problems [29]. For example, to optimise operating costs requires a reduction in the number of employees, but the leader could resist pursuing this measure since it is politically disadvantageous [30].

\subsection{CEO's membership on the boards of directors of other} companies. The literature provides analysis of the importance for the company of the share of independent directors on the board of directors of companies [31-32]. In turn, independent directors are often at the head of other enterprises [33]. It would be interesting to trace the opposite effect, that is, to determine how the representation of the leader on the board of directors of other companies can influence his activities in the context of the present study.

In-depth interviews with the directors of Russian companies conducted by Forbes in 2010 demonstrated that representation on the board of other companies contribute to self-fulfillment and professional experience in various spheres of the economy. Through participation in the board of directors of other companies, the head undergoes training, learns the specifics of other industries, and establishes business contacts at a high professional level [34]. Therefore, we can assume that the representation of the head of the board of directors of other companies has a positive impact on the financial performance of his company.

2.5. CEO education level. A high level of education allows managers to offer more optimal solutions [35]. Previous research findings point to the importance of management training. An analysis of data on the manufacturing sector in the United States revealed that the level of education of the CEO is directly related to the results of the company's performance [36]. For example, the research [37] provides evidence that the level of education of a person influences the development of the value systems of top managers in the USA. Directors who are highly qualified in accounting, finance, consulting, and law are more successful in making the right business decisions to ensure the company's success in the stock market. On the contrary, some studies have failed to establish a link between the education level of the CEO and the performance of the company [38]. Based on a sample of data from US firms, it found no significant association and the conclusion was made that business education is overrated.

There are not many works devoted to the study of the role of the leader in Russia. Among them are the works cited at [1] and [18] which examine the state of the labour market for managers in Russia, determine the degree of integration of the Russian market into the international market, and study the factors influencing the appointment of heads of enterprises (citizenship and experience in the industry). A. Chirikova, researching gender issues in the appointment of top managers in Russian companies, 
found that the problem of the 'glass ceiling' is relevant for Russia. This problem is especially widespread in the regions [39]. Based on the existing literature and economic intuition, it can be assumed that a woman's tenure as a CEO represents her accumulated work experience (e.g. in a managerial position, in the same industry, her taking part in the boards of directors of other companies, or in the public service), a high level of education in general (and business education in particular), as well as the fact that foreign specialists from developed economies were attracted to the management of the company. The age of the leader affects the market value of the company in a non-linear fashion.

\section{Research methodology}

From a methodological point of view, the analysis of the impact of personal characteristics of the CEO on the results of the company implies that solutions may be proffered in two areas: (1) methods of personal performance measurement and (2) the definition of performance indicators of the company that would reflect the perception of the financial markets and corporate signals. In addition, relevant articles differ in that they analyse either individual characteristics of managers or a whole set of characteristics.

\section{CEO characteristics and model independent variables}

Perhaps the largest number of personal characteristics of company leaders was analysed in the research cited at [40]. The authors included in the study 30 positions of personal characteristics of candidates for executive positions, dividing them into 5 thematic groups (leadership, personal, intellectual, motivational, and interpersonal). The study was based on personal interviews, which evaluated difficult to measure leadership characteristics such as self-confidence, diligence, and decisiveness. However, such assessments are largely subjective and may give distorted results. In addition, they entail significant costs for collecting and information is often not available for external analyst.

To the set of variables analysed (gender, age, work experience, citizenship), an 'ethnic' category can be added [41]. The authors of the mentioned study used ROA as a dependent variable. It was discovered that the variables of age, citizenship, and professional qualifications are significant in measuring company performance. A particularly efficacious profile in terms of efficiency proved to be the combination of a young $\mathrm{CEO}$ and an older chairman of the board. A significant disadvantage of this analysis is the omission of nonlinear forms of variables.

The study cited at [42] is devoted to issues of the impact of gender differences on the executives of the company. In addition to the extended parameters for the gender variable (e.g. the proportion of women on the board), the analysis included variables of age, the proportion of CEOs who combine several positions in the company, and the way in which these positions were obtained. As a result of the conducted event analysis it was found that female leaders are less inclined to take risks. Additionally, the authors pointed out that the appointment of a woman to the position of CEO had the same impact on the company's results as the appointment of a man.

Methodologies and results differ regarding the influence of the leader's experience and age. There are studies that have found a positive relationship between variables of managerial experience and company performance [43]. Somewhat less obvious, at first glance, were the results obtained in the study [44]: it turned out that a CEO with the existing experience in a related position in the first place tends to increase the amount of company debt, and secondly, these leaders increase the likelihood of bankruptcy. Moreover, firms that have hired ex-CEOs cannot financially catch up with more successful firms with CEOs without general managerial experience.

Some research uses non-linear relationships to assess the impact of experience and age on performance. The study cited at reference number [45] examined the issue of changes in the cost of transport companies. The authors wanted to explain the errors in the company valuation model built with financial indicators as regressors. To do this, they introduced quadratic forms for the variables of age and experience. As a result of the study, it was found that too long a tenure in the position of CEO leads to negative consequences (the real value of the company turns out to be less than the theoretical one). Similar findings were obtained for the variable of 'age'.

\section{Justification of the dependent variables of the model}

The Tobin's Q coefficient was chosen as a dependent variable as a measure of the company's market value which is an indicator of market attractiveness. However, a significant limitation of this ratio is that it does not always fully reflect the efficiency of the company, and may depend on external factors, rather than management decisions [46]. Despite this, most studies use the Tobin's Q-ratio as a measure of company value. The Tobin's Q-ratio provides the market opinion on the effectiveness of all strategic decisions of the company and the quality of the accompanying functional management policies (marketing, financial, personnel management, etc.). In other words, assuming the market is efficient, market opinion should reflect the company's fair value.

Tobin's Q is the most widely used market-based measure of performance [47]. Researchers often develop simplified formulas for Tobin's $Q$ that do not require many sources, requires only access to information that may be in the public domain, or requires the calculation of the market value of the company's long-term debt. In practice, the following approximating formula is often used [48]:

$$
\text { Approximate } \mathrm{Q}=\frac{\mathrm{MVE}+\mathrm{PS}+\mathrm{Debt}}{\mathrm{TA}},
$$


where MVE - market capitalisation of a company; PS - the value of preferred shares;

Debt - the amount of long-term and short-term liabilities; TA - total assets.

In addition, the model includes the following control variables: company size (natural logarithm of total assets), financial leverage (the ratio of the sum of short-term and long-term debt to equity in \%), capital expenditure (the ratio of capital expenditure to the total assets of the company in \%), revenue growth rate (change in revenue compared to last year in \%), state ownership (which takes the value 1 if the state's share in the authorised capital of the company is more than $50 \%$, and 0 if the share is less than $50 \%$ ). The state ownership variable also reflects the peculiarity of corporate governance in Russia. Binary variables allow you to consider the temporal structure of the data in the pooled regression.

The independent binary variabless take the value 'one' if the manager is a woman, has citizenship outside the CIS, is a member of boards of directors external to the company, previously worked in a managerial position, previously worked in the industry to which the company belongs, previously worked in government bodies, is the founder of the company, or previously worked in this company as an employee. Based on the existing system in Russia, the level of education of a leader is encoded by a rank variable that takes values from 1 to 5 with an increase in the level of education (value 1 - bachelor's / specialty degree, 2 master's degree, 3 - Ph.D, 4 - master's degree and MBA, $5-\mathrm{PhD}$ and the presence of an MBA).

\section{Data analysis}

Our database was formed on the data of 50 largest Russian non-financial companies for the period from 2011 to 2019 during which 98 CEOs worked in these companies. Companies' market capitalisation data were obtained from the Moscow Exchange website. The financial information of companies was extracted from the annual reports of the companies analysed. Biographical information and professional characteristics of managers were collected from personal pages on the official websites of companies as well as other open sources. A brief description of the companies and personal characteristics of the sampled executives is presented in Table 1.

Table 1. Descriptive statistics of the sample

\begin{tabular}{|c|c|c|c|c|c|}
\hline Variable (units) & $\begin{array}{l}\text { Number of } \\
\text { observations }\end{array}$ & Mean & $\begin{array}{l}\text { Standard } \\
\text { deviation }\end{array}$ & $\begin{array}{l}\text { Minimum } \\
\text { value }\end{array}$ & $\begin{array}{l}\text { Maximum } \\
\text { value }\end{array}$ \\
\hline Tobin's Q (units) & 434 & 0.74 & 0.76 & 0.02 & 6.43 \\
\hline Education (rank) & 450 & 2.18 & 1.25 & 1 & 5 \\
\hline Age (years) & 447 & 49.81 & 8.8 & 33 & 71 \\
\hline Tenure as CEO (years) & 450 & 7.39 & 6.65 & 1 & 27 \\
\hline Company size (bn. rub.) & 448 & 1150.38 & 2744.47 & 34.07 & 21882.35 \\
\hline Revenue growth rate, $\%$ & 447 & 8.82 & 13.88 & -58.59 & 68.7 \\
\hline Financial leverage, \% & 448 & 54.79 & 28.06 & 8.02 & 177.6 \\
\hline Capital expenditures, \% & 448 & 8.45 & 4.73 & 0.26 & 35.02 \\
\hline \multicolumn{3}{|l|}{ Variable (units) } & Total & \multicolumn{2}{|c|}{$\begin{array}{l}\text { Number of observations } \\
\text { where the variable is } 1\end{array}$} \\
\hline \multicolumn{3}{|l|}{ CEO-woman (units) } & 98 & \multicolumn{2}{|c|}{1} \\
\hline \multicolumn{3}{|c|}{ CEO Citizenship outside the CIS (units) } & 98 & \multicolumn{2}{|l|}{6} \\
\hline \multicolumn{3}{|c|}{ Member of the external board of directors (units) } & 98 & \multicolumn{2}{|l|}{39} \\
\hline \multicolumn{3}{|c|}{ Industry experience (units) } & 98 & \multicolumn{2}{|l|}{72} \\
\hline \multicolumn{3}{|c|}{ Public service experience (units) } & 98 & \multicolumn{2}{|l|}{34} \\
\hline \multicolumn{3}{|c|}{ Work experience as CEO (units) } & 98 & \multicolumn{2}{|l|}{50} \\
\hline \multicolumn{3}{|c|}{ Intra-firm CEO career (units) } & 98 & \multicolumn{2}{|l|}{42} \\
\hline \multicolumn{3}{|c|}{ Company founder (units) } & 98 & \multicolumn{2}{|l|}{7} \\
\hline \multicolumn{3}{|c|}{ Companies with a controlling stake owned by the state (units) } & 50 & \multicolumn{2}{|l|}{18} \\
\hline
\end{tabular}


The companies in the sample are heterogeneous in terms of financial and economic indicators. The average value of Tobin's Q is 0.74 which means that the market value of the company's assets is less than their book value and the market underestimates the company. The lowest values of the indicator corresponded to the crisis year of 2014 . Tobin's Q, representing the dependent variable, was not correlated with any variable.

There is only 1 woman among 98 leaders in the sample. However, the results may be underestimated due to the relatively small number of companies in the sample. According to estimates obtained in the work cited at reference number [9], which analyses the movement of managers from 1997 to 2007, the proportion of women leaders is $6.2 \%$. The author concludes that this result may indicate the presence of a "glass ceiling" problem.

Only 6 out of 98 executives are foreign citizens, including 2 which head a company with a controlling stake owned by a foreign strategic investor. 4 foreign executives work in retail chains. Large Russian business prefers to attract domestic managers, believing that they are better versed in a specific business environment. At the same time, the overwhelming majority have previous experience in the industry (72 out of 98) and a third of the sample also have experience in the public service (34 out of 98). The latter fact can be explained not only by the importance of relations with state governing bodies but also by the fact that in 18 companies out of 50 the controlling stake belongs to the state.

Almost $40 \%$ of CEOs are also members of other boards of directors. This reflects the integration process of large Russian businesses.
From public sources we managed to identify the presence of MBAs for only 19 people, mainly in the younger contingent of the sample. A quarter of CEOs hold a Ph.D. This may indicate that the owners of companies value the practical experience of the leader more than academic knowledge. The importance of experience as a marker for the choice of the head of the company is also emphasised by the fact that 42 representatives of the selected group have work experience in this company, and 50 have previous experience as a leader.

Most of the large Russian companies were founded back in the days of the USSR and the opportunity to found their own company arose after its collapse. In addition, almost 30 years have passed since the founding of large entrepreneurial firms. Hence, a small number of founders of the companies continued to work as CEOs (7 out of 98).

The average CEO age is 49.8 , which is not very high compared to other countries. The average CEO tenure is 7.39 years, which means that the CEO often remains for 2 terms in office. The record-breaking CEO for the longest term is the CEO who has been in the position for 27 years, and who is one of the founders of the company, and also a shareholder. This situation is typical for all executives and co-founders of the companies in the sample.

\section{Research results}

The hypotheses were tested using pooled regression. Initially, the data contained 450 observations, however, after excluding observations with missing indicators, 431 observations remained in the sample. The results of the regression model are presented in Table 2.

Table 2. Results of regression analysis

\begin{tabular}{|c|c|c|c|c|}
\hline Variables & $\begin{array}{c}-1 \\
\text { Tobin's Q }\end{array}$ & $\begin{array}{c}-2 \\
\text { Tobin's Q }\end{array}$ & $\begin{array}{c}-3 \\
\text { Tobin's Q }\end{array}$ & $\begin{array}{c}-4 \\
\text { Tobin's Q }\end{array}$ \\
\hline CEO gender & & & & $\begin{array}{c}-0.266^{\star *} \\
(0.089)\end{array}$ \\
\hline CEO citizenship outside the CIS & $\begin{array}{c}-0.453^{* * *} \\
(0.094)\end{array}$ & $\begin{array}{c}-0.426^{* * *} \\
(0.096)\end{array}$ & $\begin{array}{l}-0.401^{\star * *} \\
(0.097)\end{array}$ & $\begin{array}{c}-0.405^{\star \star \star} \\
(0.099)\end{array}$ \\
\hline $\begin{array}{l}\text { Member of the external board of } \\
\text { directors }\end{array}$ & $\begin{array}{l}0.284^{* * *} \\
(0.024)\end{array}$ & $\begin{array}{l}0.259^{* * *} \\
(0.023)\end{array}$ & $\begin{array}{l}0.252^{* * *} \\
(0.023)\end{array}$ & $\begin{array}{l}0.251^{\star * *} \\
(0.023)\end{array}$ \\
\hline Industry experience & $\begin{array}{c}0.221^{\star * \star} \\
(0.03)\end{array}$ & $\begin{array}{l}0.206^{\star * *} \\
(0.033)\end{array}$ & $\begin{array}{l}0.205^{\star * *} \\
(0.032)\end{array}$ & $\begin{array}{l}0.202^{\star * *} \\
(0.031)\end{array}$ \\
\hline Education & $\begin{array}{l}-0.017 \\
(0.011)\end{array}$ & & $\begin{array}{l}-0.025^{\star} \\
(0.011)\end{array}$ & $\begin{array}{r}-0.0255^{\star} \\
(0.011)\end{array}$ \\
\hline
\end{tabular}

MBA

$-0.2$

(0.033)

Public service experience

$-0.128^{\star *} \quad-0.104^{* *}$

$-0.096^{\star *}$

$-0.098^{\star *}$

(0.041)

(0.045)

(0.043) 


\begin{tabular}{|c|c|c|c|c|}
\hline Variables & $\begin{array}{c}-1 \\
\text { Tobin's Q }\end{array}$ & $\begin{array}{c}-2 \\
\text { Tobin's Q }\end{array}$ & $\begin{array}{c}-3 \\
\text { Tobin's Q }\end{array}$ & $\begin{array}{c}-4 \\
\text { Tobin's Q }\end{array}$ \\
\hline Work experience as CEO & $\begin{array}{l}0.132^{\star *} \\
(0.046)\end{array}$ & $\begin{array}{l}0.142^{\star *} \\
(0.047)\end{array}$ & $\begin{array}{l}0.143^{\star *} \\
(0.049)\end{array}$ & $\begin{array}{l}0.143^{\star *} \\
(0.048)\end{array}$ \\
\hline Intra-firm CEO career & $\begin{array}{c}-0.254^{* * *} \\
(0.054)\end{array}$ & $\begin{array}{c}-0.262^{\star * *} \\
(0.049)\end{array}$ & $\begin{array}{c}-0.261^{* * *} \\
(0.049)\end{array}$ & $\begin{array}{c}-0.262^{\star * *} \\
(0.049)\end{array}$ \\
\hline Company founder & $\begin{array}{c}1.276^{\star * *} \\
(0.233)\end{array}$ & $\begin{array}{l}1.209^{* * *} \\
(0.233)\end{array}$ & $\begin{array}{c}1.193^{\star * *} \\
(0.227)\end{array}$ & $\begin{array}{l}1.189^{* * *} \\
(0.229)\end{array}$ \\
\hline CEO change & & & $\begin{array}{l}-0.048 \\
(0.071)\end{array}$ & \\
\hline Age & $\begin{array}{l}0.058^{\star *} \\
(0.019)\end{array}$ & $\begin{array}{l}0.067^{\star * \star} \\
(0.019)\end{array}$ & $\begin{array}{c}0.068^{\star * \star} \\
(0.019)\end{array}$ & $\begin{array}{c}0.069^{* * *} \\
(0.018)\end{array}$ \\
\hline Age2 & $\begin{array}{c}-0.0006^{* *} \\
(0.0001)\end{array}$ & $\begin{array}{c}-0.0006^{\star *} \\
(0.0002)\end{array}$ & $\begin{array}{c}-0.0006^{\star * *} \\
(0.0001)\end{array}$ & $\begin{array}{c}-0.0006^{\star * *} \\
(0.0001)\end{array}$ \\
\hline Tenure as CEO & $\begin{array}{c}0.019 \\
(0.016)\end{array}$ & $\begin{array}{c}0.026 \\
(0.015)\end{array}$ & $\begin{array}{c}0.022 \\
(0.018)\end{array}$ & $\begin{array}{c}0.026 \\
(0.015)\end{array}$ \\
\hline Tenure 2 as CEO & $\begin{array}{l}-0.002^{* *} \\
(0.0008)\end{array}$ & $\begin{array}{l}-0.002^{* *} \\
(0.0008)\end{array}$ & $\begin{array}{l}-0.002^{\star *} \\
(0.0009)\end{array}$ & $\begin{array}{l}-0.002^{\star *} \\
(0.0008)\end{array}$ \\
\hline Company size & $\begin{array}{c}-0.104^{\star \star *} \\
(0.017)\end{array}$ & $\begin{array}{c}-0.084^{\star * *} \\
(0.016)\end{array}$ & $\begin{array}{c}-0.081^{\star * *} \\
(0.017)\end{array}$ & $\begin{array}{c}-0.081^{\star \star \star} \\
(0.017)\end{array}$ \\
\hline Revenue growth rate & $\begin{array}{l}0.007^{\star \star} \\
(0.002)\end{array}$ & $\begin{array}{c}0.004 \\
(0.003)\end{array}$ & $\begin{array}{c}0.004 \\
(0.003)\end{array}$ & $\begin{array}{c}0.004 \\
(0.003)\end{array}$ \\
\hline Financial leverage & $\begin{array}{c}-0.006^{\star * *} \\
(0.001)\end{array}$ & $\begin{array}{c}-0.005^{\star * *} \\
(0.0008)\end{array}$ & $\begin{array}{l}-0.005^{\star * *} \\
(0.0008)\end{array}$ & $\begin{array}{c}-0.005^{\star * \star} \\
(0.0008)\end{array}$ \\
\hline Capital expenditure & $\begin{array}{l}0.033^{\star * \star} \\
(0.005)\end{array}$ & $\begin{array}{c}0.028^{\star * *} \\
(0.005)\end{array}$ & $\begin{array}{c}0.0277^{\star * *} \\
(0.005)\end{array}$ & $\begin{array}{c}0.027^{\star * *} \\
(0.005)\end{array}$ \\
\hline $\begin{array}{l}\text { Companies with a controlling stake } \\
\text { owned by the state }\end{array}$ & $\begin{array}{c}-0.617^{\star * \star} \\
(0.05)\end{array}$ & $\begin{array}{c}-0.659^{* * *} \\
(0.049)\end{array}$ & $\begin{array}{l}-0.645^{\star * *} \\
(0.052)\end{array}$ & $\begin{array}{c}-0.648^{\star * *} \\
(0.053)\end{array}$ \\
\hline Years & \multicolumn{4}{|c|}{ Included } \\
\hline Cons & $\begin{array}{l}-0.038 \\
(0.728)\end{array}$ & $\begin{array}{l}-0.351 \\
(0.546)\end{array}$ & $\begin{array}{l}-0.333 \\
(0.533)\end{array}$ & $\begin{array}{l}-0.368 \\
(0.524)\end{array}$ \\
\hline $\mathrm{R}^{2}$ & 0.547 & 0.509 & 0.511 & 0.511 \\
\hline $\mathrm{N}$ & 431 & & & \\
\hline
\end{tabular}

Note: ${ }^{*} p<0.1,{ }^{* *} p<0.05,{ }^{* * *} p<0.01$. 
All control variables were statistically significant in all modifications of the model. The negative sign of the size of the company is explained by the fact that this variable is in the denominator of the independent variable which means that the larger the denominator, the lower the ratio of capitalisation to total assets is obtained. In turn the status of a state enterprise has a negative impact on the market value of the company.

Most of the studied independent variables turned out to be significant, which is consistent with the theory of the upper echelons and the theory of human capital. We did not test the hypothesis about the influence of gender due to a single observation that a woman was leading the company in the sample. It was not possible to confirm the hypothesis about the positive influence of the foreign citizenship of the head on the market value of the company, and the relationship turned out to be negative. On the one hand, it should be considered that only 6 foreign executives were included in the sample, and two of them represented a group of companies with a controlling foreign owner. Therefore, it would be wrong to make an unambiguous conclusion that the positive effect of a technology transfer by a foreign leader is less than the disadvantages associated with ignorance of the specifics of the Russian business environment. Rather, this hypothesis needs additional testing.

Membership of a CEO on the board of directors of other companies has a positive effect on the market value of the firm he heads. The market places a high value on top managers networking and strategic decision-making experience on the board of directors.

Our analysis revealed a positive impact of previous experience in the industry on the market value of the firm. Experience in the industry gives an idea of the specifics of its functioning, potential counterparties, methods of interaction with the state, etc., which in turn is positively met by the market. Descriptive statistics results also prove that the owners prefer to hire executives with experience in the industry.

Previous experience as CEO turned out to be a positively significant variable. This thesis is supported by the fact that the educational level was not a significant variable for the model considered. The practical experience gained by the leader is more important than academic knowledge for investors.

Our study found a negative effect of a CEO's work experience in state bodies on the company market value. It should be recalled that one of the ways to accumulate human capital in this case is to acquire connections at the state level. The result obtained may indicate that at a certain stage these advantages in terms of efficiency turn into disadvantages. A CEO with the support of the state has less incentive towards careful strategic planning and development of the firm [30]. For example, if the business contacts of a manager at the state level contribute to winning the tender for a contract, it is likely that the manager will not be involved in optimising production in order to fulfill the contract on terms that are more favourable to the customer. In turn, the optimisation of production could bring significant benefits in the conclusion and execution of other contracts. The obtained result indicates that the market values a CEO with more practical experience in market conditions, and who possesses the skills of a leader, than the ability to access and employ administrative resources.

The market apparently negatively perceives the fact of an internal promotion to CEO, fearing that a person has already formed a team for himself which may lead to selfish management of the company for his own purposes (and ignoring the interests of stakeholders). At the same time, a person from the outside can look at the company from a different angle, which may entail new ideas and strategies for the management of the company.

The status of the founder of the company has a positive effect on its market value. The market negatively perceives state-owned companies and state people, fearing that they will pursue other goals and motives for doing business while the market assesses private owners and founders positively, because they know the whole business from the inside and their goal is to further develop the business and strengthen the market.

Our analysis confirmed the presence of a nonlinear relationship between the age of the leader and the market value of the company, but the tenure of the CEO turned out to be insignificant. The results obtained support the assumption that after reaching a certain age, a manager begins to lose their business acumen, does not follow relevant trends, becomes conservative, and introduces fewer new ideas. According to the signs of the age variables, a maximum point is reached which corresponds to 49 years, after which the market starts to assess the age of the leader negatively.

\section{Conclusion}

Over the past decades the stock market continues its active development, which is the primary reason for paying close attention to the formation of a company's market value. There are many theories studying the issue. However, in an unstable business environment more and more attention are paid to the personal qualities of the top management of companies their ability to cope with non-trivial tasks, develop competent business strategies and compete in the modern market.

First of all, the growth of the company's capitalisation reflects the expectations of investors, which incorporates their view of the personality of the CEO: e.g. whether he will be able to maintain an appropriate level of the firm's work, and whether there is expediency in further investment. Therefore, it is extremely important to understand exactly what qualities of top management affect investor sentiment and the market value of the company accordingly.

Our research confirms the importance for investors of the personal characteristics of the top executives of compa- 
nies belonging to the category of 'large traded companies'. According to the data, the Russian market prefers a new CEO to be a man around 49 years old, born in the CIS, and who has experience in the industry. A valuable characteristic of a CEO is the fact that he is on the board of directors of other companies, and is also a CEO in a separate company, with less emphasis on his experience in public service.

In conclusion, it should be noted that the study has some drawbacks. Firstly, due to problematic data access the sample time period is only 9 years, which does not allow for tracing the long-term effects of the influence of managers on the market value of companies. Secondly, our analysis can be expanded to include salary information in the model, to consider the impact of a CEO having a wife and children, and having a stake in the company he leads. Finally, the characteristics of managers may be dependent on the performance of the company. That is, whether the presence of certain characteristics can account for the problem of endogeneity, which is a difficult challenge to address due to the problematic search for instrumental variables. However, we should noted that these drawbacks may also be perceived as opportunities, and potential directions of future research.

\section{References}

1. Roshchin S., Solntsev S. The labor market of top managers in Russia. Moscow: NRU HSE Publ.; 2016. 252 p. (In Russ.).

2. Rumelt R. Good strategy bad strategy: The difference and why it matters. New York: Crown Business; 2011. $336 \mathrm{p}$.

3. Daellenbach U.S., McCarthy A.M. Commitment to innovation: The impact of top management team characteristics. R\&D Management. 1999;29(3):199208. DOI: $10.1111 / 1467-9310.00130$

4. DiMaggio P.J., Powell W.W. The iron cage revisited: Institutional isomorphism and collective rationality in organizational fields. American Sociological Review. 1983;48(2):147-160. DOI: 10.2307/2095101

5. Haveman H.A. Follow the leader: Mimetic isomorphism and entry into new markets. Administrative Science Quarterly. 1993;38(4):593-627. DOI: $10.2307 / 2393338$

6. Diaz- Fernández M.C., González-Rodríguez M.R., Pawlak M. Top management demographic characteristics and company performance. Industrial Management \& Data Systems. 2014;114(3):365-386. DOI: 10.1108/IMDS-04-2013-0210

7. Hambrick D.C, Mason P.A. Upper echelons: The organization as a reflection of its top managers. The Academy of Management Review. 1984;9(2):193-206. DOI: $10.2307 / 258434$
8. Brett J.F., Cron W.L., Slocum J.W. Jr. Economic dependency on work: A moderator of the relationship between organizational commitment and performance. The Academy of Management Journal. 1995;38(1):261-271. DOI: 10.2307/256735

9. Hambrick D.C. Upper echelons theory: An update. The Academy of Management Review. 2007;32(2):334343. DOI: $10.2307 / 20159303$

10. Allen N.J., Meyer J.P. The measurement and antecedents of affective, continuance and normative commitment to the organization. Journal of Occupational Psychology. 1990;63(1):1-18. DOI: 10.1111/j.2044-8325.1990.tb00506.x

11. Brealey R., Myers S., Allen F. Principles of corporate finance $11^{\text {th }}$ ed. New York: McGraw-Hill Book Co.; 2014. $1341 \mathrm{p}$.

12. Chaganti R.S., Zimmerman M.A., Kumaraswamy A., Maggitti P., Arkles J.B. TMT characteristic, time-to IPO and firm performance. Journal of Management \& Public Policy. 2016;7(2):37-56.

13. Smith N., Smith V., Verner M. Do women in top management affect firm performance? A panel study of 2,500 Danish firms. International Journal of Productivity and Performance Management. 2005;55(7):569-593. DOI: $10.1108 / 17410400610702160$

14. Rose C. Does female board representation influence firm performance? The Danish evidence. Corporate Governance. 2007;15(2):404-413. DOI: 10.1111/j.1467-8683.2007.00570.x

15. Post C., Byron K. Women on boards and firm financial performance: A meta-analysis. The Academy of Management Journal. 2014;58(5):1546-1571. DOI: 10.5465/amj.2013.0319

16. Auden W.C., Shackman J.D., Onken M.H. Top management team, international risk management factor and firm performance. Team Performance Management. 2006;12(7/8):209-224. DOI: $10.1108 / 13527590610711778$

17. Fischer H.M., Pollock T.G. Effects of social capital and power on surviving transformational change: The case of initial public offerings. The Academy of Management Journal. 2004;47(4):463-481. DOI: $10.2307 / 20159597$

18. Brockmann E.N., Simmonds P.G. Strategic decision making: The influence of CEO experience and use of tacit knowledge. Journal of Managerial Issues. 1997;9(4):454-467.

19. Roshchin S., Khudenko K. Labor relations at foreign enterprises in Russia. In: Management. Century XX, century XXI. Moscow: Ekonomist; 2004:121-140. (In Russ.). 
20. Balkin D.B., Markman G.D., Gomez-Mejia L.R. Is CEO pay in high-technology firms related to innovation? The Academy of Management Journal. 2000;43(6):1118-1129. DOI: 10.5465/1556340

21. Finkelstein S., Hambrick D.C., Cannella A.A. Jr. Strategic leadership: Theory and research on executives, top management teams, and boards. Oxford, New York: Oxford University Press; 2009. 480 p. DOI: 10.1093/acprof:o so/9780195162073.001.0001

22. Sørensen J.B. The ecology of organizational demography: Managerial tenure distributions and organizational competition. Industrial and Corporate Change. 1999;8(4):713-744. DOI: 10.1093/icc/8.4.713

23. Waldman D.A., Ramírez G.G., House R.J., Puranam P. Does leadership matter? CEO leadership attributes and profitability under conditions of perceived environmental uncertainty. The Academy of Management Journal. 2001;44(1):134-143. DOI: $10.2307 / 3069341$

24. Iaquinto A.L., Fredrickson J.W. Top management team agreement about the strategic decision process: A test of some of its determinants and consequences. Strategic Management Journal. 1997;18(1):63-75. DOI: 10.1002/(SICI) 1097 0266(199701)18:1<63::AID-SMJ835>3.0.CO;2-N

25. Finkelstein S., Hambrick D.C. Top-managementteam tenure and organizational outcomes: The moderating role of managerial discretion. Administrative Science Quarterly. 1990;35(3):484-503. DOI: $10.2307 / 2393314$

26. Solntsev S. CEOs in Russia: Who reaches the top? Working paper WP15/2009/09. Moscow: NRU HSE; 2009. 32 p. (In Russ.).

27. Faccio M. Politically connected firms. The American Economic Review. 2006;96(1):369-386. DOI: $10.1257 / 000282806776157704$

28. Fisman R. Estimating the value of political connections. The American Economic Review. 2001;91(4):1095-1102. DOI: 10.1257/aer.91.4.1095

29. Boubakri N., Cosset J.-C., Saffar W. Political connections of newly privatized firms. Journal of Corporate Finance. 2008;14(5):654-673. DOI: 10.1016/j.jcorpfin.2008.08.003

30. Black B.S., Love I., Rachinsky A. Corporate governance indices and firms' market values: Time series evidence from Russia. Emerging Markets Review. 2006;7(4):361-379. DOI: 10.1016/j. ememar.2006.09.004

31. Ivashkovskaya I., Kukina E., Stepanova A. The impact of corporate financial architecture on economic profit: An empirical study of Russian companies in the crisis and pre-crisis periods. In: Proc. $12^{\text {th }}$ Int. sci. conf. on economic and social development (Moscow, 5-7 Apr. 2011). (In 4 vols.). Vol. 4. Moscow: NRU HSE; 2012:39-48. (In Russ.).

32. Fan J.P.H., Wong T.J., Zhang T. Politically connected CEOs, corporate governance, and post-IPO performance of China's newly partially privatized firms. Journal of Financial Economics. 2007;84(2):330357. DOI: 10.1016/j.jfineco.2006.03.008

33. Zhang Y., Rajagopalan N. CEO succession planning: Finally at the center stage of the boardroom. Business Horizons. 2010;53(5):455-462. DOI: 10.1016/j. bushor.2010.05.003

34. Filatov A.A. Why do managers become independent directors? Forbes. 2010. URL: http://www.forbes. ru/column/48736-zachem-menedzhery-idut-vnezavisimye-direktora (accessed on 5.05.2020). (In Russ.).

35. Certo S.T. Influencing initial public offering investors with prestige: Signaling with board structures. The Academy of Management Journal. 2003;28(3):432446. DOI: 10.5465/amr.2003.10196754

36. Rajagopalan N., Datta D.K. CEO characteristics: Does industry matter? The Academy of Management Journal. 1996;39(1):197-215. DOI: 10.2307/256636

37. Manner M.H. The impact of CEO characteristics on corporate social performance. Journal of Business Ethics. 2010;93(Suppl. 1):53-72. DOI: 10.1007/ s10551-010-0626-7

38. Gottesman A.A., Morey M.R. CEO educational background and firm financial performance. Journal of Applied Finance. 2010;20(2):1-13.

39. Chirikova A. Woman at the head of the company. Moscow: Institute of Sociology of RAS; 1998. 358 p. (In Russ.).

40. Kaplan S.N., Klebanov M.M., Sorensen M. Which CEO characteristics and abilities matter? The Journal of Finance. 2012;67(3):973-1007. DOI: 10.1111/j.1540-6261.2012.01739.x

41. Amran N.A., Yosuf M.A.M., Ishak R., Aripin N. Do characteristics of CEO and chairman influence government-linked companies performance? Procedia - Social and Behavioral Sciences. 2014;109:799-803. DOI: 10.1016/j.sbspro.2013.12.546

42. Martin A.D., Nishikawa T., Williams M.A. CEO gender: Effects on valuation and risk. Quarterly Journal of Finance \& Accounting. 2009;48(3):23-40.

43. Chi J., Liao J., Chen X. Political connected CEOs and earnings management: Evidence from China. Journal of the Asia Pacific Economy. 2016;21(3):397-417. DOI: $10.1080 / 13547860.2016 .1176644$ 
44. Elsaid E., Wang X., Davidson W.N. III. Does experience matter? CEO successions by former CEOs. Managerial Finance. 2011;37(10):915-939. DOI: $10.1108 / 03074351111161583$

45. Ben Mohamed E., Jarboui S., Baccar A., Bouri A. On the effect of CEOs' personal characteristics in transport firm value? A stochastic frontier models. Case Studies on Transport Policy. 2015;3(2):176-181. DOI: $10.1016 /$ j.cstp.2015.01.001

46. Pham P.K., Suchard J.-A., Zein J. Corporate governance and alternative performance measures: Evidence from Australian firms. Australian Journal of Management. 2011;36(3):371-386. DOI: $10.1177 / 0312896211413035$

47. Al-Matari E.M., Al-Swidi A.K., Hanim F. The measurements of firm performance's dimensions. Asian Journal of Finance \& Accounting. 2014;6(1):2449. DOI: 10.5296/ajfa.v6i1.4761

48. Chung K.H., Pruitt S.W. A simple approximation of Tobin's q. Financial Management. 1994;23(3):70-74. DOI: $10.2307 / 3665623$ 